\title{
Media and the Rise of Right-Wing Populism: Gauging the Role of CNews in Promoting Far-Right Ideology in France
}

\author{
Armiyaou Gombo Abdoul-Bagui ${ }^{1,2}$ \\ ${ }^{1}$ Faculty of Economics and Administration, University of Kocaeli, Kocaeli, Turkey \\ ${ }^{2}$ Faculty of Economics, ICP Paris, Paris, France \\ Email: bagui_66@hotmail.com, armiyaougombo.abdoulbagui@campusicp.fr
}

How to cite this paper: Abdoul-Bagui, A. G. (2021). Media and the Rise of Right-Wing Populism: Gauging the Role of CNews in Promoting Far-Right Ideology in France. Open Journal of Political Science, 11, 752-769. https://doi.org/10.4236/ojps.2021.114048

Received: September 20, 2021

Accepted: October 26, 2021

Published: October 29, 2021

Copyright (อ 2021 by author(s) and Scientific Research Publishing Inc. This work is licensed under the Creative Commons Attribution International License (CC BY 4.0).

http://creativecommons.org/licenses/by/4.0/ (c) (i) Open Access

\begin{abstract}
This paper reflects the concept of populism, based on an analysis of a media editorial line and the increasing populist, demagogic discourses present on mainstream media in France. It presents the concept of populism and its current problems, then offers a methodological reflection centered on the desire to emphasize the role of media on the rise of right-wing populism and far-right ideology. The aim is to study the role of media, which can promote populist communication. This study doesn't focus on contextual factors such as the electoral success of right-wing populist parties; instead, it explores other aspects, such as media editorial line and opinion journalism, largely independent of political reality which can increase the chances of populist rhetoric being included in media coverage. Therefore, this paper offers a brief review of the communicative aspect of populism. It discusses the rise of populist rhetoric in the media in France and the role of the CNews television channel in mobilizing and promoting far-right ideologies in the French political and media landscape. The results highlight how CNews, with its far-right columnists, such as Eric Zemmour, contribute to the rise of right-wing populist rhetoric in the French media landscape; since the increase of its audience coincides with the rise of right-wing populist and far-right rhetoric in the French political spectrum.
\end{abstract}

\section{Keywords}

France, Right-Wing Populism, Media Discourse, CNews, Far-Right

\section{Introduction}

The recent success of populist movements worldwide has renewed academic in- 
terest in the phenomenon of populism and its driving forces. The role of the media in promoting right-wing populist rhetoric has been the subject of extended research. Media, disinformation, and populism have attracted significant attention in recent years. The media play a crucial role in the political sphere as they construct or produce information, interact with politicians, and affect political processes at different levels (Hallin \& Mancini, 2004). The hypothesis posed is that media coverage plays a crucial role in the rise of right-wing populist rhetoric (Walgrave \& de Swert, 2004) and promoting far-right ideology in France.

The proliferation of information in social media easily accessible forces the mainstream media to adopt new strategies. People are looking for free and open discussion spaces without taboos, where all subjects are discussed without any restriction or censorship. The conformism on mainstream media arouses an inevitable rejection, which explains some media's choice of new editorial line breaking the tradition (Valeurs Actuelles, 2020).

In France, CNews editorial line and its communication strategy reflect the reality of the trivialization of the far-right ideology in the French media landscape. It might influence the success of the far-right political parties such as the Marine Le Pen's Rassemblement National (RN) and Nicolas Dupont-Aignan's Débout la Republique (DLF) in the coming elections.

While assuming that the media play a crucial role in the rise and success of populist movements, there are very few literatures and researches on populist political communication. Indeed, most of the literature in political science neglects the communicative aspect of populism. Therefore, our paper seeks to fill this gap with data from media thematic content analysis of controversial verbal and textual statements on CNews TV set and far-right journalists such as Eric Zemmour. This paper analyzes the thematic included in CNews' editorial line and Eric Zemmour's populist discourses and compares them with right-wing and far-right main thematic. Our study pointed out the growing transformation of the news channel editorial line. The case of CNews is more than evidence of the rising populist rhetoric in mainstream media (Valeurs Actuelles, 2020). This strategy is part of a particular context where far-right and populist parties are more popular and social networks have become alternative media for many people.

The main subject of our study is the communicative aspect of right-wing populism and the role of media in promoting right-wing ideology. Following the framework of discursive opportunities (Gamson, 1988), this study argues that media and political communication may favor specific rambling messages; and the success of far-right and populist parties might also influence the editorial line of mainstream media. Our study focuses on the case of the CNews channel, which has gained in popularity since its creation in 2017.

This paper is organized as follows. First, our literature review consisted in developing our theoretical background and documenting the concept of media and 
populism. We carried out a literature review on what has already been done regarding the role of the media in the rise of right-wing populism. Most of these work focuses on the increasingly populist editorial lines of some mainstream media. Second, the collection of verbal and textual content allowed us to analyze CNews' editorial line. Finally, our paper explores Eric Zemmour's communication style and his different strategies used to increase CNews audiences and mobilize the right-wing and far-right public.

\section{Media and Populism}

Several theoretical and empirical studies argue that populist discourses relayed by the media can significantly impact voters' opinions and behaviors (Hameleers et al., 2019). Some researchers say that the electoral success of populist parties cannot be fully explained without considering how the media covers and sometimes disseminates populist rhetoric within the population (Krämer, 2014).

Several studies support that populist communication often uses strongly negative messages that constitute a crisis narrative (Moffitt, 2016b; Moffit \& Tormey, 2014). Populist leaders and media paint a dark picture of the situation and explain to their audiences why they should be worried and why they should blame someone or some group of people (Reinemann et al., 2020). Therefore, populist movements see the media as essential political instruments for mobilizing support and maintaining close relationships with the public and private media (Mazzoleni, 2014). On the other hand, the media tend to support populism based on ideological communion, economic advantage, or political calculations (Tumber \& Waisbord, 2021). The growing success of populist parties triggered the emergence and growing development of populist rhetoric by mainstream media and politicians (Mudde, 2004).

Almost all liberal democracies are affected by the populism phenomenon, either in the discursive style (Mudde, 2007; Moffitt, 2016a) or as an ideology (Mudde \& Kaltwasser, 2013). Furthermore, almost all politicians embrace populism at the level of political communication: While mainstream political parties cannot imitate populist parties in their policies, they imitate populist leaders in their rhetoric, particularly during the elections (Mudde, 2004).

Populism manifests itself on several levels. Public opinion can echo populist positions; mainstream and social media can convey populist rhetoric (Flew \& Losifidis, 2019); political parties, movements, and leaders can be associated with populist agendas. The populist movement favors direct contact with "the people", in particular via social media, or during the talk shows in the mainstream media, offers "alternative point of view, or even fake news for a specific audience (Nielsen, 2020). From Donald Trump to Jair Bolsonaro to Viktor Orbán and Rodrigo Duterte, populist leaders are questioning the fundamental role of the media and journalism in politics. However, some mainstream media are becoming a platform for spreading populist rhetoric and, by doing that, favor the 
rise of right-wing populism and far-right ideologies.

\subsection{Defining Media}

A media is an impersonal medium allowing extensive and collective dissemination of information or opinions, whatever the means: radio, television, the press, books, advertising, etc. It relays communication to a vast number of people without the possibility of personalizing the message. Lisa Gitelman (2006) defines media as "socially realized structures of communication, where structures include both technological forms and their associated protocols, and where communication is a cultural practice, a ritualized collocation of different people on the same mental map, sharing or engaged with popular ontological representation. As such, media are unique and complicated historical subjects. Their histories must be social and cultural" (Gitelman, 2006). Media are also the spaces of action for constructed attempts to connect what is separate (Zielinski, 2006). They modulate vibrations whose contrasts produce other entities and new fabrics of relationality (Hansen, 2015).

Bruno Latour distinguishes between intermediaries, who are expected to transmit information without transforming it, and mediators, who are known to alter what they change. The communicator is never a pure intermediary; any transmission involves translation, adaptation, mediation (Latour, 2014). For Jussi Parikka, media are not the substance or the form through which actions take place but an environment of relationships in which time, space, and capacities for action emerge. Therefore, media consist less of mediations or communications between humans than an environment of engagement or relationality for objects, vectors, agency, and processes that enter the human sphere (Parikka, 2011). Thus, media plays an essential role in the transmission of information and, by doing that, influences the social and political sphere (Kivijärvi \& Takala, 2020). In France, mainstream media play a crucial role in mobilizing public opinion.

However, the media are confronted with the same drift as that of the political parties. They are giving a voice to "ordinary" people on different thematic generally reserved for the political or economic elite, for experts, leaving people the possibility of giving their own opinion. This politically incorrect is irremediably called "populism".

Today, the word "media" covers very different realities. The distance between an endangered written press and the audio-visual media grows every day; evolution appears under the pressure of this new information vector: the Internet (Pessey, 2014). Indeed, in recent years, mainstream media, outclassed by social networks, tend to succumb to populist rhetoric to attract more audiences (Moffitt, 2018). Through permanent fantasies, xenophobic and Islamophobic statements are irrigating the media landscape spectrum in France. Indeed, populism and the media seem to form an unlikely couple, which influences France's socio-political life. 


\subsection{Concept of Populism}

Most researchers define populism as a thin ideology that considers that society is separated between two camps that are both homogeneous and perfectly antagonistic, "the pure people" and "the corrupt elite". Indeed, several researchers agree that populism is a political attitude that consists in dividing society into two entities; on the one hand, there would be the elites, misguided and corrupt, who would be in opposition to the "people" victim and considered as a single entity (Mudde \& Kaltwasser, 2018; Camus \& Lebourg, 2015). Populist leaders claim to be the spokespersons of people who are by nature right against corrupt elites. Claimed by some as a banner of their defense of people whose sovereignty would be confiscated by a corrupt elite, populism is also an aversion aimed at disqualifying those who advocate a break with the current political and economic system. Populism is undoubtedly one of the most contested concepts in the social sciences, insofar as it creates a sort of "cacophonous" field of research (Dézé, 2004).

However, the concept of populism is so controversial that researchers have not reached a consensus around its definition (de la Torre \& Arson, 2013) since "there are no terms more elusive than populism" (Mayer, 2005). Populism has been used in different situations and different periods of history (Taguieff, 1998). Thus, it is complicated to analyze populism, and there are many attempts to define the concept (Dorna, 2003). Populist leaders are skilled communicators, on mainstream media, through the instrumentalization of the press and their particularly effective use of social networks (Krämer \& Holtz-Bacha, 2020).

In the book "Perspectives on Populism and the Media" (2020), Benjamin Krämer argues that there are significant implications for defining populism as either an ideology, a style, a discourse or a concept and that "populism is often defined about the distinctions it makes or the antagonisms it creates" (Krämer \& Holtz-Bacha, 2020). Benjamin Krämer classifies the definitions of populism into four categories. First, he defines populism as an ideology. He believes populism as an ideology is a concept rarely used in traditional communication research but is used more substantially. For example, he argues that populism is used as a variable measuring someone's position on the left-right axis of the political spectrum (Krämer \& Holtz-Bacha, 2020).

Secondly, the discursive approach of populism is often associated with the work of Ernesto Laclau (2008). It analyzed the general logic of populism by which the historically contingent unmet demands of populations are articulated in such a way as to treat them as equivalent in the face of antagonism between the people and the elite (Krämer \& Holtz-Bacha, 2020).

Third, according to Benjamin Krämer's classification, populism can be defined as a style. Style is a concept that can quickly come to mind when one talks about communication. There are styles of speech, styles of writing, looks, and manners. Style has been defined very differently in research on populism. Another aspect of populism concerns habitus, physical performance, leadership 
style (Casullo, 2020; Moffitt, 2016a), language, rhetoric, and argumentation (Ekström et al., 2018).

Pierre-André Taguieff defines populism as "a political style based on the appeal to the people as well as on the worship and defense of the people, compatible in principle with all political ideologies" (Taguieff, 2007). Finally, according to Krämer, populism can be defined as a strategy. This definition is often seen as an alternative approach. However, while this approach may seem natural in populism and the media, it is often not elaborated very explicitly. Populism is perceived as "a specific way of competing and exercising political power" (Weyland, 2021), rather opportunistic in terms of politics but a strategy that aims to gain the support of the masses around a charismatic leader (Krämer \& Holtz-Bacha, 2020).

Nayla Fawzi pointed out the paradoxical relationship between populism and the media. On the one hand, the media is often cited as an essential factor in the rise of populism in modern democracies (Krämer \& Holtz-Bacha, 2020). They offer platforms of opportunities for populist leaders and columnists. A populist logic that includes provocative statements is often made by a populist leader or a polemicist editorialist (Mazzoleni, 2014). On the other hand, there are often criticisms towards the mainstream media by populist leaders (Krämer \& Holtz-Bacha, 2020). In the United States, former US President Donald Trump constantly criticizes the media for their bias and accuses them of being "fakes" (Krämer \& Holtz-Bacha, 2020).

For populism, a consensus seems to be developing around certain essential elements, which can be reflected in political positions and communicative discourse (Krämer, 2018). The first important element that characterizes populism is supposedly homogeneous people who are claimed to be suffering, neglected, disadvantaged, and even threatened. Putting these 'people' first is the most fundamental perspective of populism (Mudde, 2004). Consequently, populism emphasizes the importance of the "people" as in-group and favors identification. It makes the in-group and its situation the critical point of reference in the political discourse (Laclau, 2008).

Pierre-Andre Taguieff (1998) distinguishes two types of populism in Europe: reactionary (protestor) populism and national-populism (identity). Reactionary populism is expressed through a vote, a party, or a mobilization. It is possible to identify it with an ideological-political style. A political movement can be called reactionary populist when the motivations for the rally are dissatisfaction and discontent (González-Ruibal, González, \& Criado-Boado, 2018). This can be observed, for example, through demonstrations, involvement in protest movements, rejections, or abstention during the elections (Aron \& Superi, 2021). A protest vote can be characterized as a vote against someone or a system. This type of vote is also qualified to express a crisis of representation or confidence in political representatives (Taguieff, 2012).

The second type of populism is the one that focuses on the nationalist or ethnic-nationalist aspect (Bonikowski, 2017), and it is called national-populism or 
identity nationalism. Taguieff explains it as a type of populism that appeals to the people to fix the threats against the nation's existence (Spruyt, Keppens, \& Van Droogenbroeck, 2016). Right-wing populists stigmatize minorities and immigrants who are supposed to represent a threat to the natives (Jamin, 2017). Furthermore, national-populists denounce the elites accused of being the origin of the problem (Taguieff, 2012).

In the 1990s, populism became a "popular" and controversial term in the media landscape (Freeman, 2018). Populism then became a means of delegitimizing and stigmatizing (Taguieff, 1998). In France, Marine Le Pen's Rassemblement National (RN) increased its vote bank. RN scored $24.86 \%$ in the European elections of 2014, and it confirmed this progression in the 2015 regional elections, leading to $27.73 \%$ in the first round. In the presidential election of $2017, \mathrm{RN}$ positioned itself as the second political party in France (France-politique.fr). Indeed, populist politics is gradually becoming popular in France. Many of its representatives are already present in several European Union countries' governments, especially since the financial, economic, and social crisis of 2008 and the migration crisis of 2015 (Jihan, 2017).

Populists' leaders have also succeeded and taken power in different countries outside the European Union. The case of the United Kingdom with Boris Johnson, the United States with Donald Trump, Brazil with Jair Bolsonaro, India with Narendra Modi, and the Philippines with Rodrigo Duterte, etc., are the most evident example of the rise of right-wing populism in the world. In all these countries, populists' leaders share the same ideas but are different ideologically and in political practices (Dorna, 2005). Populism also threatens democracy, globalization, and international institutions (Zhai \& Xu, 2020).

\section{Methodology}

Before developing our methodology, let's emphasize our problem: what is the role of the CNews channel on the rise of right-wing populism in France? CNews seems to become the primary tool of communication for the far-right and right-wing movements in France. To answer our research question and test our hypothesis, the work of Pierre Paillé and Alex Mucchielli, "L'analyse qualitative en sciences Humaine et Sociales" (2008), allowed us to develop our research method. Among the strategies proposed by the authors, we have opted for the thematic content analysis (TCA). Thematic analysis is a method of analysis consisting in "identifying, in verbal or textual expressions, general recurring themes which appear under various and more concrete contents" (Mucchielli, 1996). In other words, the thematic analysis consists of the identification, grouping, the discursive examination of the themes addressed in a corpus (Paillé \& Mucchielli, 2012).

This paper focuses on discursive, stigmatizing statements held on the CNews channel sets by journalists close to the French far-right and Eric Zemmour's communication strategy. Indeed, for populist and far-right parties, media be- 
come an essential tool for their electoral fortunes (Bos et al., 2010; de Vreese et al., 2010). We used systematic content analyses of CNews media outlets between 2019 and 2021 and compared the thematic with right-wing populist party leaders. Using NVivo, we extract the central thematic from verbal, textual, and visual data collected. The qualitative software helps us to identify the central thematic we need for our research. The analysis of the collected data reveals four thematic mains, which are essential for populist and far-right leaders' agendas in France. The central thematic is; immigration, Islam, identity, and security. These topics are used by right-wing and far-right parties to increase their vote bank and used by CNews columnists to draw audiences. We collected several articles from newspapers "Liberation" and "Le Figaro" and many other newspapers with contrasting editorial lines, from the left and the right of the French political spectrum. The thematic content analysis consists of identification and documentation (Herzog, Handke, \& Hitters, 2019). The identification function is to enter all the themes of a corpus, which corresponds, in our case, to the collection of verbal or textual expressions and general recurring themes which appear under various and more concrete contents, and the main themes developed by CNews columnists. The documentation function draws parallels or differences between the themes included in the CNews editorial line and the themes used by imminent right-wing populists' figures in France to increase their electorate.

Our methodology further outlines the different steps we followed to answer our main research question. These steps constitute our research protocol. It underlies the results we produce to verify our hypothesis, suggesting that CNews and its far-right editorialists play a significant role in the rise of right-wing populism in France.

Our first hypothesis suggests that the growing visibility of far-right columnists such as Eric Zemmour in CNews TV shows is a political strategy to increase the far-right vote bank in the coming elections. The second hypothesis suggests that CNews is a platform for promoting right-wing populism and far-right ideology in France. Our third hypothesis suggests that Eric Zemmour shares the same ideology with some imminent figures of the French national populism on the thematic of Islam, immigration, identity, and security. Considering the context, we chose controversial statements and different thematic developed by Eric Zemmour between 2019 and 2021 to illustrate the radical right-wing of CNews' editorial line. Then, we draw parallels and differences between the themes included in the CNews editorial line and those developed by imminent right-wing populists' figures such as Marine Le Pen and Nicolas Dupont Aignan.

\section{Analyzing CNews Editorial Line}

Mainstream media have gone through significant changes in the last few decades. These changes have included radicalizing their editorial line and disseminating populist messages in their news coverage (Esser et al., 2017). The mainstream media's role in the rise of right-wing populism in Europe and the United 
States is the subject of heated debate and research, as they are the primary communication structure. In recent years, media has become an essential communication tool to convey populist rhetoric.

Europe has been facing a phenomenon of "rise" or even populist "danger in recent years. In France, the CNews channel is a perfect example of right-wing populism in the media.

Driven by two TV shows, "L'Heure des Pros" and "Face à l'Info", according to data from Mediametrie, an organization founded in 1985 with the aim of mea-suring audiences and carrying out marketing studies on French media, whether television, radio, cinema or the Internet, the CNews channel saw its audiences increase to a peak audience of $2.7 \%$ in May 2021, while it struggled to get $0.7 \%$ a year earlier. Populist editorialists Pascal Praud gathered hundreds of thousands of viewers, and the far-right journalist Eric Zemmour blew up the channel's visibility. Stigmatizing minorities, opposing political elites, appealing to the conspiracy theory are the common denominators of all populisms that flourish in the political and media arena. In opposition to mainstream media, nowadays, populist parties seem to find a sort of allies within the French media landscape (Fawzi, 2017). CNews appears to contribute to the diffusion of the far-right ideologies and might become a considerable asset for the right-wing populist parties such as the Rassemblement National (RN) and Debout la Republique (DLF) in the coming elections.

With his supposedly expressive words, clashes, and punchy comments, CNews continues to gain traction among the French public. Its trajectory is reminiscent of Fox News in the United States and it might play a significant role in the 2022 presidential election in France. However, it is difficult to measure the impact of a television channel on a poll, as in 2005, when the media advocated a "yes" in the referendum on the European constitution, but finally, the "no" won at the polls. In CNews TV shows, far-right journalists such as Pascal Praud and Eric Zemmour give the impression that they speak on behalf of a collective or behalf of the French population. That is why Nicolas Lebourg underlines a "brutalization of the rules of speech and the standards of civility" by CNews (L'Express, 2021).

For David Cormand EELV Eurodeputy, CNews "is no longer a news channel but a far-right channel, where there are all prejudices, commonplaces and logorrhea" (L'Union, 2021). Indeed, the talk shows and open debates are the "favorite game" of the far-right columnists. Commenting on various subjects, politicizing fear, browsing polls: their positions and statements on different thematic such us Islam, security, immigration attract more audiences. If racist and Islamophobic "slippages" can occur almost daily, it is also because the media agenda and editorial lines allow them. An agenda that gives a privileged place to the thematic of the far-right and right-wing populism: security issues and "controversies" over Islam are present in each debate, whether they are deployed through the commentary of various facts or "decryption" of political communi- 
cation. Thus, editorialists and politicians multiply populist rhetoric, and journalists close to the far-right and national populist movements increasingly occupy TV news sets.

News channels have been shifting from news platforms into open debate and news analysis platforms in recent years. They are no more only simple relays of information; they are participating in public debate as well. In July 2020, Le Figaro headlined in an article entitled plus dopinion et moins de "robinet à info" à la television (Le Figaro, 2020) that literary means more opinion and less news on TV channels. However, this strategy arouses heavy criticism. Marc-Olivier Fogiel, the head of BFMTV, another French TV news, in an interview with Le Parisien, in July 2020, described CNews as "a right-wing, and divisive opinion channel" (Valeurs Actuelles \& Juillet, 2020). For several critics, CNews is the French version of Fox News (Liberation, 2021a). According to journalist Ivan Rioufol, there was a need for fresh air, and the public need something new.

The process of the radicalization of CNews' editorial line appears to be logical as the main topics of concern among the French population are developed at the right of the political spectrum. The right-wing rise from the people's discomfort, there are strong concerns, and CNews becomes a mirror of the people affected by this discomfort. Security and immigration are the primary concern of the French people and are on the top agenda of the French far-right. CNews uses a far-right editorial line to increase the audience to the detriment of the democratic debate. The guests and the thematic treated on the CNews set show a growing far-right editorial line evolution. In addition, several journalists close to the French far-right are the privileged guests of the talk shows.

As the editorial lines of the news channels slide into the far-right, right-wing populist parties are increasing their popularity. Standardizing columnists such as Eric Zemmour and Pascal Praud seem to help Marine Le Pen. By recruiting Eric Zemmour, CNews is sure to cause controversy. So, people attracted by curiosity could vote for the far right. The data collected by the newspaper "La Liberation" showed that CNews is the channel that grants the most audiences to far-right guests. According to the data collected by Liberation (Liberation, 2021b), far-right guests represented more than $36 \%$ of the total guests over one year. Left-wing parties represent only $17 \%$ of CNews guests, while they represent $25 \%$ of political guests.

\section{Eric Zemmour's Communication Strategy and His Impact on CNews Editorial Line}

According to François Jost, a semiologist, media specialist, "there is a shift into the far-right of the news channels editorial line". A political positioning is a matter of strategy. For him, the three channels, BFM, CNews, and LCI, have suspicious behavior that helps Marine Le Pen electorate (Yahoo Actualités, 2019).

This change of editorial line is to retain an audience with ideas close to the 
far-right with a far-right editorial line. The most prominent evidence of the CNews editorial line marked on the far-right is the crucial role played by its famous far-right polemist Eric Zemmour. For some observers, CNews uses a cynical strategy to reach a population segment with an ideology close to the French far-right.

Outgroup exclusion is central to right-wing populist ideology and generally refers to ethnic or religious minorities such as refugees, immigrants, or Muslims. Populists try to establish the image of a society in crisis and portray exogroups as a threat to the in-group. They refer to a heartland, an emotional construct of idealized past times where the people's will be implemented, and populist outgroups are marginalized (Taggart, 2000). Nowadays, in France, Eric Zemmour is one of the prominent figures of the right-wing populism and far-right, and its presence in CNews sets to boost the channel audiences and the rise of populism in the media (La Croix, 2019).

Stigmatizing minorities and creating polemic is the primary strategy used by Eric Zemmour to draw an audience to the CNews channel. In 2019, he argues that all French problems are aggravated by immigration and Islam" (Liberation, 2019) and announces that he shares Renaud Camus' conspiracy theory of the "great replacement". Furthermore, Eric Zemmour evoked an "occupation", a "reversed colonization", and the "extermination" of "white heterosexual Catholic man" (Liberation, 2019). Several complaints were filed against Eric Zemmour after this discourse.

French right-wing populists share the same fear of the great replacement of the French population by a supposed Muslim and African people. This theory is also shared by imminent figures of the French far-right such as Marine Le Pen et Nicolas-Dupont Aignant. Nicolas Dupont-Aignan asserts that if France doesn't control migratory flows, the French population will be replaced (Liberation 2017). For the historian, Gérard Noiriel, specialist of immigration in France, the CNews polemist Eric Zemmour uses the same identity thematic as the anti-Semitic writer Edouard Drumont, one of the imminent figures of the French far-right. He points out the responsibility of the TV channels, specially CNews, which gives him a platform (Liberation, 2019).

For Eric Zemmour, French people should be conservative of their identity, and that French identity precedes all others (Convention de la Droite, 2019). His discursive strategy is based on his identity character, which presents the situation in France as a tragedy: France is the victim, and Islam and uncontrolled immigration are the aggressors (La Croix, 2019). For Eric Zemmour, the terrorist attacks would be a prelude to civil war, the "war of civilization" that risks transforming France into a "French Islamic Republic" (Convention de la Droite, 2019).

By recruiting Eric Zemmour, CNews changed its editorial line and became a sort of French "Fox News". His presence in the TV shows allowed CNews to increase its audiences. According to data collected by La Liberation, one month 
after his arrival to CNews, Eric Zemmour gathered an average of 194,000 viewers, or 1\% audience share (figures Médiamétrie), between October 14 and November 20, 2019. In May 2021, CNews' audience reached 2.7\% to become the first French news channel.

For several observers, CNews becomes a platform for the liberalization of xenophobic and populist rhetoric. In a TV show in "Face à I Info", Eric Zemmour declared to be supportive and "on the side of General Bugeaud", who "massacred Muslims, and even some Jews in Algeria. That's what being French!” (Pure Medias, 2019). However, his Islamophobic discourses are not always shared by some imminent figures of the French far-right such as Marine Le Pen and Nicolas-Dupont Aignant. They believe in the compatibility between Islam and the French Republic.

Eric Zemmour embarked on another xenophobic verbal statement in the CNews set despite his condemnation for his Islamophobic discourse. He claims that immigrants are all thieves, murderers, and rapists and should stop coming to France (Midi Libre, 2020). Eric Zemmour attacks the immigrants he describes as thieves and murderers, and he uses the CNews TV show to propagate populistic propaganda. This is typical populist rhetoric shared by most far-right figures in France.

Linking immigration with insecurity is a strategy used by Marine Le Pen and Nicolas Dupont Aignant to increase their vote bank. Indeed, in 2013 after the publication of a study by L'Observatoire national de la délinquance (the National Crime Observatory) pointing the increase of foreigners among people accused to be thefts, Marine Le Pen affirmed that "there is a link between immigration and insecurity" (L'Express \& AFP, 2013).

Eric Zemmour plays the game of division to boost far-right ideology. He enjoys strong notoriety in the French media landscape for his ability to create debate through divisive statements, mainly on national identity and security issues. Thus, CNews becomes, for him and other far-right journalists, a leading platform. With his radical position on identity, security, Islam, and migration, Éric Zemmour has become controversial. Thanks to the CNews channel, he manages to disseminate his ideologies massively.

\section{Conclusion}

This study has shown that a media influenced by the rise of national populism and the growing success of alternative media, such as social networks, adopt a far-right editorial line. This study found proximity between CNews and right-wing and far-right ideology in France, which may inform future research on populism and media. We demonstrated that media editorial lines matter when it comes to gaining an audience. They don't hesitate to recruit polemist journalists close to the far-right and use populist rhetoric in their news coverage. Our results show that by recruiting Eric Zemmour, CNews plays a significant role in promoting populist rhetoric, favoring the rise of far-right and right-wing 
populism. Eric Zemmour uses the media sets to build polemics around sensitive subjects (La Croix, 2019), the thematic used by far-right and populist parties to increase their vote bank. By adopting an editorial line close to the far-right and giving a platform for far-right columnists, CNews has increased its audience since 2019. At the same time, right-wing populist far-right parties have increased their vote bank. Thus, our data analysis shows a parallel progression; on the one hand, the media are adopting a far-right editorial line. On the other hand, far-right parties are gaining support from the population.

However, the main question that remains unresolved is whether the increase in support to the far-right parties influenced the editorial line of media such as CNews or if the media plays a role in mobilizing and increasing support for far-right and national populism in France. Both scenarios might be possible since the media and political parties use the same strategy to grow, whether their audience or electorate.

\section{Conflicts of Interest}

The author declares no conflicts of interest regarding the publication of this paper.

\section{References}

Aron, H., \& Superti, C. (2021). Protest at the Ballot Box: From Blank Vote to Populism. Party Politics. https://doi.org/10.1177/1354068821999741

Bonikowski, B. (2017). Ethno-Nationalist Populism and the Mobilization of Collective Resentment. The British Journal of Sociology, 68, S181-S213. https://doi.org/10.1111/1468-4446.12325

Bos, L., van der Brug, W., \& de Vreese, C. (2010). Media Coverage of Right-Wing Populist Leaders. Communications, 35, 141-163. https://doi.org/10.1515/comm.2010.008

Camus, J. Y., \& Lebourg, N. (2015). Extreme Rights in Europe [ENG]. Les droites Extrêmes en Europe [ORG]. Seuil.

Casullo, M. (2020). The Body Speaks Before It Even Talks: Deliberation, Populism and Bodily Representation. Journal of Deliberative Democracy, 16, 27-36. https://doi.org/10.16997/jdd.380

de la Torre, C., \& Arnson, C. (Eds.) (2013). Latin American Populism in the Twenty-First Century. The Johns Hopkins University Press.

de Vreese, C., van der Brug, W., \& Bos, L. (2010). Media Coverage of Right-Wing Populist Leaders. Communications, 35, 141-163. https://doi.org/10.1515/comm.2010.008

Dézé, A. (2004). Le populisme ou l'introuvable Cendrillon. Autour de quelques ouvrages récents. Revue Française de Science Politique, 54, 179-190.

Dorna, A. (2003). Neopopulism and Charisma. In La Découverte (Ed.), The populist Temptation in the Heart of Europe (pp. 89-100). Recherches. https://doi.org/10.3917/dec.ihl.2003.01.0089

Dorna, A. (2005). Populism, a Notion Populated by Particular Stories in Search of a Unifying Paradigm [ENG]. Avant-propos: Le Populisme, une notion peuplée d'histoires particulières en quête d'un paradigme fédérateur [ORG]. Amnis, Revue d'études des 
sociétés et cultures contemporaines Europe-Amérique. Open Edition Journals.

Ekström, M., Patrona, M., \& Thornborrow, J. (2018). Right-Wing Populism and the Dynamics of Style: A Discourse-Analytic Perspective on Mediated Political Performances. Palgrave Communications, 4, Article No. 83. https://doi.org/10.1057/s41599-018-0132-6

Esser, F., Stepinska, A., \& Hopmann, D. N. (2017). Populism and the Media: Cross-National Findings and Perspectives. In T. Aalberg, C. de Vreese, J. Strömbäck, F. Esser, \& C. Reinemann (Eds.), Populist Political Communication in Europe (pp. 365-380). Routledge. https://www.routledge.com/Populist-Political-Communication-in-Europe/Aalberg-Ess er-Reinemann-Stromback-De-Vreese/p/book/9781138654792

Fawzi, N. (2017). Beyond Policy Agenda-Setting. Political Actors' and Journalists' Perceptions of News Media Influence across All Stages of the Political Process. Information, Communication \& Society, 21, 1134-1150. https://doi.org/10.1080/1369118X.2017.1301524

Flew, T., \& Losifidis, P. (2019). Populism, Globalization and Social Media. International Communication Gazette, 82, 7-25.

Freeman, D. (2018). Populism, and Media Policy Failure. European Journal of Communication, 33, 604-618. https://doi.org/10.1177/0267323118790156

Gamson, W. A. (1988). Political Discourse and Collective Action. International Social Movement Research, 1, 219-244.

Gitelman, L. (2006), Always Already New. Media, History and the Data of Culture (p. 7). MIT Press. https://doi.org/10.7551/mitpress/1208.001.0001

González-Ruibal, A., González, P. A., \& Criado-Boado, F. (2018). Against Reactionary Populism: Towards a New Public Archaeology. Antiquity, 92, 507-515. https://doi.org/10.15184/aqy.2017.227

Hallin, D., \& Mancini, P. (2004). Comparing Media Systems. Three Models of Media and Politics. Cambridge University Press. https://doi.org/10.1017/CBO9780511790867

Hameleers, M., Reinemann, C., Schmuck, D., \& Fawzi, N. (2019). The Persuasiveness of Populist Communication: Conceptualizing the Effects and Political Consequences of Populist Communication from a Social Identity Perspective (1st ed.). Routledge. https://doi.org/10.4324/9780429402067-8

Hansen, M. B. N. (2015). Feed-Forward. On the Future of 21st Century Media (p. 231). University of Chicago Press.

Herzog, C., Handke, C., \& Hitters, E. (2019). Analyzing Talk and Text II: Thematic Analysis. In H. Van den Bulck, M. Puppis, K. Donders, \& L. Van Audenhove (Eds.), The Palgrave Handbook of Methods for Media Policy Research (pp. 385-401). Palgrave Macmillan. https://papers.ssrn.com/sol3/papers.cfm?Abstract_id=3068081 https://doi.org/10.1007/978-3-030-16065-4_22

Jamin, J. (2017). Populism in the United States: The People's Question [ENG]. Le populisme aux Etats-Unis: La question du peuple [ORG]. Amnis. http://journals.openedition.org/amnis/3232

Jihan, A. (2017). Europe's Refugee Crisis: Right-Wing Populism and Mainstream Cooption in Germany and France. CUNY Academic Works. https://academicworks.cuny.edu/cc_etds_theses/731

Kivijärvi, M., \& Takala, T. (2020). (De)Stigmatization of Political Leadership: The Case of a Right-Wing Populist Presidential Candidate in the Finnish Media. Open Journal of Political Science, 10, 428-447. https://doi.org/10.4236/ojps.2020.103026

Krämer, B. (2014). Media Populism: A Conceptual Clarification and Some Theses on Its 
Effects. Communication Theory, 24, 42-60.

Krämer, B. (2018). Populism, Media, and the Form of Society. Communication Theory, 28, 444-465. https://doi.org/10.1093/ct/qty017

Krämer, B., \& Holtz-Bacha, C. (2020). Perspectives on Populism and the Media, Avenues for Research (1st ed.). Nomos. https://doi.org/10.5771/9783845297392-1

Laclau, E. (2008). On populism Reason [ORG]. La Raison populiste [FR]. Le Seuil.

Latour, B. (2014). Media et modes d'existence. INA Global, No. 2.

Mayer, N. (2005). Radical Right Populism in France: How Much of the 2002 Le Pen Votes Does Populism Explain?

https://www.researchgate.net/publication/228957645_Radical_Right_Populism_in_Fra nce_How_much_of_the_2002_Le_Pen_votes_does_populism_explain

Mazzoleni, G. (2014). Mediatization and Political Populism. In F. Esser, \& J. Strömbäck (Eds.), Mediatization of Politics (pp. 42-56). Palgrave Macmillan. https://doi.org/10.1057/9781137275844_3

Moffitt, B. (2016a). The Global Rise of Populism. Performance, Political Style, and Representation. Stanford University Press. https://doi.org/10.11126/stanford/9780804796132.001.0001

Moffitt, B. (2016b). The Populism/Anti-Populist Divide in Western Europe. Democratic Theory, 5, 1-16. https://doi.org/10.3167/dt.2018.050202

Moffitt, B. (2018). Populism and media in Western Europe. In C. de la Torre (Ed.), Routledge Handbook of Global Populism (pp. 235-248). Routledge. https://doi.org/10.4324/9781315226446-19

Moffitt, B., \& Tormey, S. (2014). Rethinking Populism: Politics, Mediatisation and Political Style. Political Studies, 62, 381-397. https://doi.org/10.1111/1467-9248.12032

Mucchielli, A. (Éd.) (1996). Dictionary of Qualitative Methods in Human and Social Sciences [ENG]. Dictionnaire des méthodes qualitatives en sciences humaines et sociales [ORG]. Armand Colin.

Mudde, C. (2004). The Populist Zeitgeist. Government and Opposition, 39, 541-563. https://doi.org/10.1111/j.1477-7053.2004.00135.x

Mudde, C. (2007). Populist Radical Right Parties in Europe. Cambridge University Press. https://doi.org/10.1017/CBO9780511492037

Mudde, C. (2016). Europe's Populist Surge: A Long Time in the Making. Foreign Affairs, 95, 25-30.

Mudde, C., \& Kaltwasser, R. (2018), Brief Introduction to Populism [ENG]. Breve introduction au populisme [ORG]. Fondation Jean Jaures. https://doi.org/10.1093/actrade/9780190234874.001.0001

Mudde, C., \& RoviraKaltwasser, C. (2013). Exclusionary vs. Inclusionary Populism: Comparing Contemporary Europe and Latin America. Government and Opposition, 48, 147-174. https://doi.org/10.1017/gov.2012.11

Nielsen, G. (2020). Populism, Fake News, and the Flight from Democracy. In K. Dalkir, \& R. Katz (Eds.), Navigating Fake News, Alternative Facts, and Misinformation in a Post-Truth World (pp. 238-257). IGI Global. https://doi.org/10.4018/978-1-7998-2543-2.ch011

Paillé, P., \& Mucchielli, A. (2012). Qualitative Analysis in Humanities and Social Sciences [ENG]. L'analyse qualitative en sciences humaines et sociales [ORG]. https://doi.org/10.3917/arco.paill.2012.01

Parikka, J. (2011). Media Ecologies and Imaginary Media: Transversal Expansions, Con- 
tractions, and Foldings. The Fibreculture Journal, No. 17, 35.

https://www.fibreculturejournal.org

Pessey, C. (2014). Le populisme dans les medias. Humanisme, 4, 49-54. https://doi.org/10.3917/huma.305.0049

Reinemann, C., Stanyer, J., Aalberg, T., Esser, F., \& deVreese, C. H. (2020). Communicating Populism: Comparing Actor Perceptions, Media Coverage, and Effects on Citizens in Europe. Routledge. https://doi.org/10.4324/9780429402067

Spruyt, B., Keppens, G., \& Van Droogenbroeck, F. (2016). Who Supports Populism and What Attracts People to It? Political Research Quarterly, 69, 335-346.

https://www.jstor.org/stable/44018014

https://doi.org/10.1177/1065912916639138

Taggart, P. (2000). Populism, Buckingham, and Philadelphia. Open University Press.

Taguieff, P.-A. (1998). Populisms and Antipopulisms: The Clash of Arguments [ENG]. Populismes et antipopulismes: Le choc des arguments [FR]. Les Langages du Politique, 55, 5-26. https://www.persee.fr/doc/mots_0243-6450_1998_num_55_1_2343 https://doi.org/10.3406/mots.1998.2343

Taguieff, P.-A. (2007). The Populist Illusion [ENG]. L'illusion populiste [FR]. Book ed. Flammarion.

Taguieff, P.-A. (2012). The New National-Populism [ENG]. Le nouveau national-populisme [ORG]. Collection Débats, Paris, Éditeur CNRS Éditions.

https://doi.org/10.3917/cnrs.tagui.2012.01

Tumber, H., \& Waisbord, S. (Eds.) (2021). The Routledge Companion to Media Disinformation and Populism (1st ed.). Routledge.

https://doi.org/10.4324/9781003004431-1

Walgrave, S., \& de Swert, K. (2004). The Making of the (Issues of the) Vlaams Blok. Political Communication, 21, 479-500. https://doi.org/10.1080/10584600490522743

Weyland, K. (2020). Populism's Threat to Democracy: Comparative Lessons for the United States. Perspectives on Politics, 18, 389-406.

https://doi.org/10.1017/S1537592719003955

Weyland, K. (2021). Populism as a Political Strategy: An Approach's Enduring-And Increasing-Advantages. Political Studies, 69, 185-189.

https://doi.org/10.1177/00323217211002669

Zhai, X. Y., \& Xu, Y. Y. (2020). Populism Poses a Threat to International Security. Open Journal of Political Science, 10, 481-492. https://doi.org/10.4236/ojps.2020.103029

Zielinski, S. (2006). Deep Time of the Media. Toward an Archaeology of Hearing and Seeing by Technical Means (p. 7, 30). MIT Press, 2006. (Original title: Archäologie der Medien. Zur Tiefenzeit des technischen Hörens und Sehens, Rheinbeck, Rohwolt, 2002).

\section{Press Articles}

L'Express \& AFP (2013). Marine Le Pen: “There Is Obviously a Link between Immigration and Insecurity" [ENG], Marine Le Pen: "Il y a évidemment un lien entre immigration et insécurité" [ORG]. LEXPRESS.fr avec AFP.

https://www.lexpress.fr/actualite/politique/video-marine-le-pen-il-y-a-evidemment-un -lien-entre-immigration-et-insecurite_1308313.html

L'Union (2021). Television: CNews Arouses Attraction and Repulsion among Politicians [ENG]. Télévision: CNews suscite attraction et répulsion chez les politiques [ORG]. L'Union.

https://www.lunion.fr/id261054/article/2021-05-29/television-cnews-suscite-attraction- 
et-repulsion-chez-les-politiques

La Croix (2019). Gérard Noiriel: "We Must Not Forget the Lessons of the Past", by Bilkis Blanc published on November 15, 2019 [ENG]. Gérard Noiriel: “Il ne faut pas oublier les leçons du passé”, La croix en ligne, par Bilkis Blanc publié le 15 novembre 2019. [ORG]. https://www.la-croix.com/France/Gerard-Noiriel-Il-faut-pas-oublier-lecons-passe-2019 $\underline{-11-15-1201060715}$

Le Figaro (2020). More Opinion and Less "News Tap" on Television by Caroline Sallé [ENG]. Plus d'opinion et moins de "robinet à info" à la télévision Par Caroline Sallé, Publié le 20/07/2020.

https://www.lefigaro.fr/medias/plus-d-opinion-et-moins-de-robinet-a-info-a-la-televisi on-20200720

L'Express (2021). Nicolas Lebourg: Eric Zemmour embodies a "nationalism obsessed with decadence" [ENG]. Nicolas Lebourg: Eric Zemmour incarne un "nationalisme obsédé par la décadence" [ORG].

https://www.lexpress.fr/actualite/politique/nicolas-lebourg-eric-zemmour-incarne-unnationalisme-obsede-par-la-decadence_2144164.html

Liberation (2017). Dupont-Aignan Joins the Wave of the "Great Replacement". Liberation published by Pauline Moullot and Vincent Coquaz on January 18, 2017 [ENG]. Dupont-Aignan rejoint la vague du "grand remplacement". Liberation publié par Pauline Moullot et Vincent Coquaz le 18 janvier 2017 [ORG].

https://www.liberation.fr/politiques/2017/01/18/dupont-aignan-rejoint-la-vague-du-gr and-remplacement_1542378

Liberation (2019). Gérard Noiriel: “Eric Zemmour's Words Are a Half-Word Incitement to Civil War" [ENG]. Gérard Noiriel: "Les propos d'Eric Zemmour sont une incitation à demi-mot à la guerre civile" Liberation [ORG].

https://www.liberation.fr/debats/2019/10/01/gerard-noiriel-les-propos-d-eric-zemmou r-sont-une-incitation-a-demi-mot-a-la-guerre-civile_1754672/

Liberation (2021a). CNews, a French Fox news? By David Colon, Professor and Researcher at Sciences Po's History Center. Published on July 5, 2021 [ENG]. CNews, un Fox news français ?par David Colon, enseignant-chercheur au centre d'histoire de Sciences Po. publié le 5 juillet 2021 [ORG].

https://www.liberation.fr/idees-et-debats/cnews-un-fox-news-francais-20210705_UA4J Z754JBA5JNAR3QCFQGVCRU/

Liberation (2021b). 36\% of CNews Politicalguests Are Far-Right [ENG]. 36\% des invités politiques de CNews sont d'extrême droite. Liberation June, 14, 2021.

https://www.liberation.fr/economie/medias/36-des-invites-politiques-de-cnews-sont-d extreme-droite-20210614_TP4X4N2KC5AHHHR7AH3ULWI6WU/

Midi Libre (2020). Controversy: Eric Zemmour Describes Unaccompanied Minor Migrants as "Rapists", “Ass-Sassins", “Thieves" Posted on October 01, 2020 [ENG]. Polémique: Eric Zemmour qualifie les migrants mineurs isolés de "cvioleurs", “assassins", "voleurs" Publié le 01 octobre 2020 [ORG].

https://www.midilibre.fr/2020/10/01/polemique-eric-zemmour-qualifie-les-migrantsmineurs-isoles-dassassins-violeurs-voleurs-9110226.php

Pure Medias (2019). "I Am on the Side of General Bugeaud”: Eric Zemmour Defends the Colonial Massacres in Algeria on CNews published by Christophe Gazzano Thursday, October 24, 2019 [ENG]. "Je suis du côté du général Bugeaud": Eric Zemmour fait l'apologie des massacres coloniaux en Algérie sur CNews publié par Christophe Gazzano Jeudi 24 Octobre 2019 [ORG].

https://www.ozap.com/actu/-je-suis-du-cote-du-general-bugeaud-eric-zemmour-fait-l- 
$\underline{\text { apologie-des-massacres-coloniaux-en-algerie-sur-cnews/584990 }}$

Valeurs Actuelles (2020). A "Very Right-Wing" "Opinion Channel”: BFMTV Cheif Manager Marc-Olivier Fo-Giel Lashes Out at CNews [ENG]. Une "chaîne d'opinion" "très à droite": Le patron de BFMTV, Marc-Olivier Fogiel, s'en prend à CNews [ORG]. Valeurs Actuelles.

https://www.valeursactuelles.com/culture/une-chaine-dopinion-tres-a-droite-le-patron -de-bfmtv-marc-olivier-fogiel-sen-prend-a-cnews/

Yahoo Actualités (2019). CNews, LCI, BFM: Are the News Channels Playing the Game of the National Gathering? [ENG]. CNews, LCI, BFM: Les chaînes infos font-elles le jeu du Rassemblement national?

https://fr.news.yahoo.com/c-news-lci-bfm-les-chaines-infos-fontelle-le-jeu-du-rassemb lement-national-080011302.html

\section{Videos Contents}

https://www.dailymotion.com/video/x7wkp7l

https://www.dailymotion.com/video/x80cyep

https://www.dailymotion.com/video/x7ut2co

https://www.dailymotion.com/video/x7ut4i0

Convention de la Droite (2019). Eric Zemmour's Speech [ENG]. Discours intégral d'Eric Zemmour [ORG]. https://www.youtube.com/watch?v=TeoaJMx_hc0 